\title{
The Inclusion of Border Carbon Adjustments in Preferential Trade Agreements: Policy Implications
}

Kateryna Holzer / Nashina Shariff ${ }^{1}$

\begin{abstract}
Preferential Trade Agreements (PTAs) are an increasingly important part of the global trading system. At the same time Border Carbon Adjustments (BCAs) are begining to be considered a necessary policy tool to address the carbon leakage and competitiveness concerns associated with emissions pricing systems. This confluence of events begs the question - Is there a useful role for BCAs in the implementation of PTAs? This paper provides an initial review of the rationale for going this policy direction, options for implementing BCAs through PTAs, and the legal implications of these options.
\end{abstract}

The paper argues that the inclusion of BCAs in PTAs has several distinct advantages: it may avoid the trade retaliatory measures that could arise from the unilateral imposition of BCAs, it does not rely on cumbersome and often ineffective multilateral discussions, and it might be more legally feasible as it provides a method of, to some extent, circumventing barriers to the unilateral imposition of BCAs posed by WTO rules. The paper explores policy options for implementing BCAs through PTAs, incuding looking at the importance of the BCA rate, the role of rules of origin, and the manner in which bilateral negotiations can help along the implementation process, even in cases where BCAs are, in the end, implemented unilaterally. The paper concludes that PTAs can indeed play a useful role in implementing BCAs, suggesting that this is a policy worth further exploration.

\footnotetext{
${ }^{1}$ Kateryna Holzer is a Doctoral Fellow at the World Trade Institute and participant in the Swiss National Centre of Competence in Research on Climate Change (NCCR Climate) and Swiss National Centre of Competence in Research on Trade Regulation (NCCR Trade Regulation). Nashina Shariff is a graduate student at the University of Bern pursuing a Masters in Climate Sciences. Research for this paper was funded by the Swiss National Science Foundation.
} 


\title{
The Inclusion of Border Carbon Adjustments in Preferential Trade Agreements: Policy Implications
}

\author{
Kateryna Holzer and Nashina Shariff
}

\section{Introduction}

Preferential trade agreements (PTAs) are growing in importance in globally. In 1990 there were approximately 70 preferential trade agreements in place, by 2010 there were around $300 .^{2}$ Free trade agreements make up around three quarters of the PTAs. ${ }^{3}$ According to the EU:

Free Trade Agreements (FTAs), if approached with care, can build on WTO and other international rules by going further and faster in promoting openness and integration, by tackling issues which are not ready for multilateral discussion and by preparing the ground for the next level of multilateral liberalization. ${ }^{4}$

Border carbon adjustments (BCAs) as trade related climate policy measures have also been increasing in prominence in global discussions. In countries with stringent carbon pricing systems in place BCAs can be used to charge a carbon price on imports and rebate the carbon price on exports. These measures are primarily aimed at addressing two trade related concerns:

1) Competitiveness concerns - concerns that industries that face higher costs due to carbon prices may become less competitive and as a result lose global

\footnotetext{
2 World Trade Report 2011 - The WTO and preferential trade agreements: From co-existence to coherence (WTO 2011), at p. 6.

${ }^{3}$ The WTO Agreement distinguishes between two types of PTAs - "a free trade area, FTA" and "a customs union, CU". A free-trade area is defined as "a group of two or more customs territories in which the duties and other restrictive regulations of commerce ... are eliminated ... between the constituent territories...". A customs union is defined as "the substitution of a single customs territory for two or more customs territories, so that (i) duties and other restrictive regulations of commerce are eliminated ... between the constituent territories of the union" (i.e. not to all WTO members on an MFN basis) This paper concentrates on the former form of PTAs as the most relevant in the context of BCA practice. BCAs are considered primarily in trade relations between developed and advanced developing countries, which are unlikely to go beyond FTAs for a higher level of integration of a customs union.
}

${ }^{4}$ Global Europe: Competing in the world - A contribution to the EU's Growth and Jobs Strategy (European Commission 2006), at p. 10, available on the Internet at http://trade.ec.europa.eu/doclib/docs/2006/october/tradoc_130376.pdf (last accessed on 18 March 2012). 
market share to competitors in countries that do not have commensurate policies in place. $^{5}$

2) Carbon leakage - the concern that carbon reductions could be diluted by increased production in more carbon intensive countries. ${ }^{6}$

The proliferation of these two policies raises the question of whether BCAs may have some role to play in the upcoming PTAs.

The following paper explores this question. It begins by providing some background on PTAs and BCAs. It goes on to address the question of whether BCAs can usefully play a role in PTAs by exploring the rationale for such a system. Finally, it explores options for implementing BCAs through PTAs and the legal implications of these options.

\section{Background}

\section{Preferential Trade Agreements}

It is widely understood that multilateral agreement on trade issues provides the most efficient means of encouraging trade globally. ${ }^{7}$ PTAs are criticized because while they can increase trade among PTA parties they can also decrease trade with non-PTA parties, leading to welfare losses. ${ }^{8}$ None the less, many countries see PTAs as a means to move forward on issues that can find no resolution at the multi-lateral level. ${ }^{9}$ As a result while some see PTAs as "termites" in the multi-lateral system, ${ }^{10}$ many view them as a catalyst that can push the multi-lateral trading system towards the desired level of openness.

\footnotetext{
${ }^{5}$ L. Parker and J. Blogdett, "Carbon Leakage" and Trade: Issues and Approaches, Congressional Research Services Report for Congress (Congressional Research Service 2008), at p. 1, available on the Internet at http://www.fas.org/sgp/crs/misc/R40100.pdf (last accessed on 30 April 2012).

${ }^{6}$ Ibid.

7 See e.g. World Trade Report 2011 at note 2, at p. 94.

${ }^{8}$ World Trade Report 2011 at note 2, at p. 100.

${ }^{9}$ EC 2006 at note 4.

${ }^{10}$ J. Bhagwati, Termites in the Trading System: How Preferential Agreements Undermine Free Trade (Oxford University Press 2008).
} 
The 300 PTAs currently in force include the participation of practically all WTO members - both developed and developing countries. ${ }^{11}$ Importantly, trade liberalization is not the only driver for the conclusion of PTAs. In fact, preferential tariff margins constitute no more than $1 \%$ of trade due to the already low Most Favoured Nation (MFN) tariffs ${ }^{12}$, particularly on industrial products, that have arisen as a result of a series of liberalization rounds in the GATT/WTO. ${ }^{13}$ As such, negotiations under PTAs have increasingly been used to promote non-trade policy objectives, known as WTO-X commitments, including environmental and labour standards. $^{14}$

Although PTAs constitute a separate trade regulatory system, it has been subject to compliance with the multilateral trade system since the conclusion of the GATT in 1947. GATT Article XXIV establishes requirements of the multilateral trade system to regional and bilateral trade relations and thereby facilitates coexistence and coherence of trade relations at the two levels. ${ }^{15}$ The WTO normative framework of regional trade is based on the common understanding that the formation of PTAs implies the liberalization of trade on a non-MFN basis, which is a derogation from the MFN obligations of countries under the WTO Agreement. This derogation of MFN treatment under PTAs is however foreseen, and thus permitted, by WTO rules. ${ }^{16}$

\footnotetext{
${ }_{11}$ World Trade Report 2011 at note 2, at pp. 54-57.

12 Under the WTO rules, tariffs applied to the most favoured nation (i.e. the lowest rate a country applies) must be applied by the WTO member country in normal (non-preferential) multilateral trade relations to all imports irrespective of their origin. These tariffs are known as MFN tariffs.

${ }^{13}$ Ibid., at p. 86.

${ }^{14}$ Ibid., at p. 63 and pp. 128-129.

${ }^{15}$ With the creation of the WTO, separate requirements, albeit similar to those in GATT Article XXIV for trade in goods under PTAs, were made in GATS Article V for trade in services under PTAs. See T. Cottier \& M. Foltea „Constitutional Functions of the WTO and Regional Trade Agreements", in L. Bartels \& F. Ortino (eds.) Regional Trade Agreements and the WTO Legal System (Oxford University Press 2006), at p. 47. There is also a separate set of WTO requirements that apply to PTAs formed solely between developing countries in the Enabling Clause. The Enabling Clause was originally a Decision of GATT contracting parties in 1979 on Differential and more favourable treatment, reciprocity and fuller participation of developing countries, whose main purpose was to allow unilateral (non-reciprocal) preferences of developed countries to developing countries. Since the creation of the WTO, the Enabling Clause has received a status of a permanent exception to GATT rules.
}

\footnotetext{
${ }^{16}$ For instance, paragraphs 5 and 8 of GATT Article XXIV provide that, subject to certain conditions, "the provisions of ... [the GATT] shall not prevent, as between the territories of contracting parties, the formation of a customs union or of a free-trade area”.
} 
While PTAs began in the form of regional trade agreements, finding its roots in the increasing regionalism in Europe in the 1950s, ${ }^{17}$ they have now expanded beyond regional blocks so that today, half of all PTAs are not regional in nature. ${ }^{18}$ There is also a particular rise in PTAs between developed and developing nations. In 2005, of the 141 PTAs in goods in place, 36 were between developed and developing nations. ${ }^{19}$

Major developed nations including the U.S. and the EU have been expanding the number of these agreements in the past few years and are looking to further expand it in the future. Currently, the U.S. has PTAs in place with a wide variety of countries. Agreements include the North American Free Trade Agreement and the Dominican Republic-Central American Free Trade Agreements. It also has PTAs in place with Australia, Bahrain, Israel, Jordan, Morocco, Oman, and Singapore. It has recently signed PTAs with Columbia, Korea and Panama that are not yet in force and it is working on an Asia Pacific trade agreement known as the Trans-Pacific Partnership Agreement. $^{20}$

Through its Global Europe Strategy the EU is also currently pursuing a strategy of negotiating PTAs with a number of countries. ${ }^{21}$ PTAs have recently been concluded with South Korea and Chile. It is also currently negotiating agreements with the Association of South-East Asian Nations (ASEAN), Canada, the Gulf Cooperation Council, India, Malaysia, Singapore and the Ukraine. China has also been identified as meeting the economic criteria for new PTA partners, though the Commission notes that it presents special opportunities and risks. ${ }^{22}$

\footnotetext{
17 World Trade Report 2011 at note 2, at p. 6.

${ }^{18}$ World Trade Report 2011 at note 2, at p. 6. Hence, the term "Preferential Trade Agreements" is more proper than the traditional term "Regional Trade Agreements".

${ }^{19}$ J. Crawford and R. V. Fiorentino, "The Changing Landscape of Regional Trade Agreements", World Trade Organization Discussion Paper (WTO: Geneva 2005).

${ }^{20}$ Office of the United States Trade Representative - Executive Office of the President, available on the Internet at http://www.ustr.gov/trade-agreements/free-trade-agreements (last accessed on 18 March 2012).

${ }^{21}$ EC 2006 at note 4.

${ }^{22}$ EC 2006 at note 4, at p. 11.
} 
The north-south PTAs that are so prevalent in these negotiations may be of particular relevance to the BCA debate as it is between developed and developing countries that the gap in climate policies is most pronounced.

\section{Border Carbon Adjustments}

BCAs are taxes or regulations imposed on the importation or exportation of goods as an adjustment of domestic carbon-related measures (carbon taxes, emissions allowance requirements etc.) at the border. BCAs have been widely discussed in recent times and have shown up in numerous policy proposals. Most notably, the Waxman Markey Bill proposed in the U.S. looked at requiring importers to submit allowances to account for their emissions. ${ }^{23}$ They have also been discussed in the context of European policy. While currently carbon leakage and competitiveness concerns are dealt with in the European Union's Emissions Trading System (EU ETS) primarily through the free allocation of allowances, the EU notes that a "carbon equalization system" could be put in place to put energy intensive industries that are at significant risk of carbon leakage on a comparable footing with those in third countries. ${ }^{24}$ Most recently, by including international aviation in the EU ETS the EU has essentially put the idea of "carbon equalization" in practice. ${ }^{25}$

\section{a. Purpose and effectiveness of BCAs}

Addressing the competitiveness impacts on industry is arguably the most important role of BCAs. Competitiveness concerns are intertwined with carbon leakage concerns arising primarily from the Pollution Haven Hypothesis which predicts that “...liberalized trade in goods will lead to the relocation of pollution intensive

${ }^{23}$ H.R. 2454 -- American Clean Energy and Security Act of 2009, Section 767 c) and 768, available on the Internet at http://thomas.loc.gov/cgi-bin/query/D?c111:4:/temp/ c111t5xdS0:: (last accessed on 18 March 2012).

24 Directive 2009/29/EC of the European Parliament and of the Council of 23 April 2009 amending Directive 2003/87/EC so as to improve and extend the greenhouse gas emission allowance trading scheme of the Community Text with EEA relevance, Official Journal L 140, 05/06/2009 P. 0063 - 0087, Section 25.

25 The EU requires domestic and foreign passenger and cargo airlines to surrender emissions allowances on flights starting and ending in EU airports, The measure, which was enacted by the EU ETS Directive on 1 January 2012, has evoked international opposition threatening to escalate in retaliations, litigations and trade wars. This issue is currently being dealt with through consultations among countries in the International Civil Aviation Organisation (ICAO) in the hopes of settling these disputes in an amicable manner. 
production from high income and stringent environmental regulation countries, to low income and lax environmental regulation countries." ${ }^{26}$ Results confirming this hypothesis are mixed, none-the-less, these issues have featured prominently in the climate change debate. ${ }^{27}$

A number of studies have been completed in an attempt to quantify the impacts of carbon leakage from the enactment of carbon pricing policies. For example, the IPCC's fourth assessment estimates carbon leakage rates that would result from action under Kyoto range from 5 to $20 \% .{ }^{28}$ A number of other studies have estimated leakage impacts from the implementation of the EU's post-2012 climate policies, the results show that leakage could range from $2 \%$ to greater than $100 \%$, based on a number of different modeling assumptions. ${ }^{29}$ The OECD has stated definitively the likelihood of carbon leakage, indicating that "[m]odel simulations indicate that the use of economic instruments to reduce greenhouse gas emissions is likely to have negative impacts on the international competitiveness position of some industrial sectors, especially when such instruments are implemented in a non-global manner.”30 An IISD study shows that the likelihood of carbon leakage is most significant in the long-run, when the mobility of resources increases and countries will choose to make their new investments in "pollution havens". ${ }^{31}$

\footnotetext{
${ }^{26}$ M.S. Taylor, "The Pollution Haven Hypothesis - Unbundling the Pollution Haven Hypothesis" 4 (2) Advances in Economic Analysis \& Policy (2004), at p. 3.

${ }^{27}$ For example, a review of recent studies found "statistically significant pollution haven effects of reasonable magnitude.” However, a review of U.S. manufacturing between 1972 and 1994 found that while trade liberalization occurred and U.S. manufacturers reduced pollution "[a] shift toward cleaner industries has also occurred among U.S. imports". See Ederington et al., "Trade Liberalization and Pollution Havens”, 4 (2) Advances in Economic Analysis \& Policy (2004) and L. Parker and J. Blogdett "Carbon Leakage" and Trade: Issues and Approaches, Congressional Research Services Report for Congress (2008), at p. 1.
}

${ }^{28}$ T. Barker et al., "Mitigation from a cross-sectoral perspective", in B. Metz, et al. (eds.), Climate Change 2007: Mitigation. Contribution of Working Group III to the Fourth Assessment Report of the Intergovernmental Panel on Climate Change (Cambridge University Press 2007), at p. 622.

${ }^{29}$ L. Parker and J. Blogdett, at note 5.

30 The Political Economy of Environmentally Related Taxes, Organization for Economic Cooperation and Development, Executive Summary, at p. 2, available on the Internet at http://www.oecd.org/dataoecd/27/23/36966499.pdf (last accessed on 18 March 2012).

31 P. Wooders and A. Cosbey, "Climate-linked tariffs and subsidies: Economic aspects (competitiveness and leakage) ", TAIT Conference Background Paper (2010), at p. 4, available on the Internet at http://www.wto.org/english/res_e/reser_e/climate_jun10_e/climate_jun10_e.htm (last accessed on 18 March 2012). 
A recent OECD study notes that there is a growing consensus among computable general equilibrium (CGE) modelers that the overall impacts on carbon leakage from emissions pricing policies are nominal, however energy intensive industries that are exposed to international competitiveness may none the less see sizable impacts. There is little research available on whether BCAs do in fact reduce carbon leakage. However this OECD study concludes that BCAs can reduce leakage for small coalitions of acting countries such as the EU. ${ }^{32}$

BCAs have also been suggested to have other purposes. By taxing imports they place a carbon price on the emissions of goods consumed, which can be important from an environmental perspective. For example, studies have shown that in the US 7.3 per cent of emissions are related to imports, for Germany this value is 16.6 per cent and for Switzerland it is as high as 122.9 per cent. ${ }^{33}$ They may also provide an incentive for developing countries to adopt their own carbon pricing policies, as in this way those countries would be able to collect the revenue from the policy themselves and invest it in low carbon technologies in their own countries.

\section{b. Design of BCAs}

The design of BCAs will have impacts on their ability to address competitiveness concerns, their effectiveness in accomplishing climate policy goals as well as on the likelihood that BCAs will in fact be considered consistent with international trade law.

There are a number of ways BCAs can be designed. ${ }^{34}$

\footnotetext{
32 J. Burniaux, "Is there a Case for Carbon-based Border Tax Adjustment? An Applied Equilibrium Analysis", OECD Economics Department Working Papers no. 794, available on the Internet at http://www.oecd.org/officialdocuments/displaydocumentpdf/?cote=ECO/WKP(2010)50\&doclanguage=en (last accessed on 18 March 2012).

${ }^{33}$ G. P. Peters and E. G. Hertwich, "CO2 Embodied in international trade with implications for global climate policy", 42 (5) Environmental Science and Technology (2008), at pp. 1401-1407.

${ }^{34}$ This discussion applies to import side BCAs. Export rebates normally but not necessarily accompany import border adjustments in order to level playing field for exporters in world markets. With respect to their form, export rebates should mirror import BCAs, e.g. if the import-side BCA taxes emissions based on best available technology (BAT), exporters would
} 
1) Processes and production methods (PPMs) - the BCA level is set by applying the carbon price to the actual emissions in imported products (i.e. based on the emissions level in industries of the exporting country).

2) Best Available Technology (BAT) - the BCA is applied based on some benchmark linked to the best (least carbon-intensive) technology commercially available for producing the product. This benchmark could be based on the best available technology in the importing country, the exporting country or both.

3) Predominant method of production (PMP) - a technology that has a considerable market share in the importing country is used as a benchmark (e.g. $60 \%$ of the firms in the corresponding sector of the importing or exporting country). ${ }^{35}$

4) Average emissions - either of the importing or exporting country.

BCA levels can also be set based only on direct emissions, i.e. the emissions directly emitted in the production of the product or using indirect emissions as well, which would include upstream emissions, for example the emissions from the production of electricity used in the production of the product.

PPM based methods for applying BCAs are the most effective means of putting in place BCAs from an emissions reduction perspective. Under this method the actual emissions created in the production of the product is used to set the BCA rate, as a result the BCA captures the full carbon impact of the product. This is also the method that would be considered by domestic producers to do the most to address competitiveness concerns as it treats foreign and domestic producers in exactly the same manner.

BAT based BCAs on the other hand would be less effective than PPM based methods from an emissions reduction perspective. If carbon emissions are taxed based on BAT in the importing country only a portion of imported emissions will face a carbon price and as a result the product would not face the full extent of the desired price signal. In this case foreign producers would face fairly low prices, meaning they are no worse

receive a rebate based on BAT as well, in order to avoid the situation where domestic producers who intend to sell their products on the domestic market would find it economic to export and re-import their products in order to lower their carbon costs.

35 The PMP can be calculated based on the emissions levels only within the the importing country's sector or it can be the PMP used in the entire world. See Matthew Genasci "Border Tax Adjustments and Emissions Trading: The Implications of International Trade Law for Policy Design", 1 CCLR (2008), at p. 37. 
off than domestic producers and will likely be better off than those domestic producers with emissions intensities greater than BAT. From the perspective of domestic producers this could put foreign producers at an unfair advantage because they face a less stringent climate policy.

PMP based BCAs would do more to address carbon leakage and the competitiveness concerns of domestic producers. A PMP method would likely have a higher benchmark level than BAT thereby pricing more but again not all emissions of imported products. It would also mean that imported products faced a price comparable to that which the majority of the domestic industry face, meaning it is likely to go further towards addressing the competitiveness concerns of domestic industry.

The effect of BCAs based on average emissions would depend on whether the average emissions of the importing or the exporting country are used. If the average emissions of the importing country is used its effect would be similar to the PMP method, pricing more emissions than BAT and placing a price on foreign goods that is comparable to that faced by most domestic producers. On the other hand if average emissions in the exporting country are used the result is similar to the PPM method. Emissions will be close to fully priced therefore the system will be more effective from the perspective of accomplishing climate policy goals, foreign producers will also face prices that are more reflective of their actual emissions and therefore would be treated in almost the same manner as domestic producers.

\section{c. Legality of BCAs}

The legal implications of BCAs have been widely examined in the literature. ${ }^{36}$ However there is no clear consensus on the legality of such measures, rather it likely depends on their design.

\footnotetext{
${ }^{36}$ This paper focuses on the adjustment of carbon taxes at the border as the most general case, with the same basic rules applying to the adjustment of emissions allowance systems. However, it is important to note that non-fiscal domestic measures (regulations) can also be adjusted at the border. Their adjustment is subject to the MFN and the national treatment principles under Articles 2.1 and 2.2, respectively, of the Agreement on Technical Barriers to Trade (TBT) for technical regulations relating to products or PPM characteristics, including labels, and under Articles I and III, respectively, of the General Agreement on Tariffs and Trade (GATT) for domestic regulations affecting sale of products in a broader sense. For a more detailed overview of the WTO rules applicable to border adjustment, see Kateryna Holzer "Proposals on carbon-related border adjustments: Prospects for WTO Compliance", 1 CCLR (2010), at pp. 51-64.
} 
From a legal perspective PPM based BCAs face perhaps the steepest hurdles. First, PPM-related taxes are neither direct nor purely indirect taxes but rather a separate, third, category of taxes called occulte taxes ${ }^{37}$. The question of whether occulte taxes can be adjusted have not been agreed upon by WTO members. Therefore, the legality of adjusting these taxes at the border is questionable.

Second, on the import side, the assessment of compliance with the National Treatment (NT) and MFN requirements relies on the outcomes of the products' likeness test. In simple terms, for judgment of compliance with the NT provisions, likeness between an imported product at issue and a like domestic product (or between groups of imported and domestic products at issue) must first be established, while for an MFN violation, likeness between an imported product at issue and a like imported product of another origin (or between groups of products of different origin) needs first to be found. ${ }^{38}$ The likeness test is liable to find that no matter how the product is produced - with high emissions or low emissions technology, products with the same physical properties, end uses, consumer perceptions and tariff classification (the four criteria of likeness that have constantly been relied upon by WTO panels and the AB) are like products. Once this determination has been made, the treatment between like products is compared in order to judge if there is discrimination under NT rules - which involves comparing imported products against their domestic counterparts, and under MFN rules - which involves comparing imported products of one origin against imported products of another origin. Consequently, steel produced in the exporting country $\mathrm{X}$ using the high carbon-emitting technology of a basic oxygen furnace will probably be found to be like a product produced in the importing country Y using the modern technology of electric arc furnace and, as the steel produced in country $\mathrm{X}$

${ }^{37}$ Taxes occultes are defined in the report of the GATT Working Party on Border Tax Adjustments as taxes, which include consumption taxes on capital equipment, auxiliary materials and services used in the transportation and production of other taxable goods, for example, taxes on energy, machinery, transport and advertising. See GATT Working Party Report on BTAs (1970), para. 15.

38 There is a large body of WTO jurisprudence related to the issue of likeness and discrimination under the GATT. Key cases on GATT Article III:2 (the national treatment obligation with respect to application of internal taxes or charges) include Japan-Alcoholic Beverages II (DS8, DS10, DS11). Korea - Alcoholic Beverages (DS75, DS84), India-Additional Duties (DS360), Philippines-Distilled Spirits (DS396, DS403). For GATT Article III:4 (the national treatment obligation with respect to internal regulations), see EC-Asbestos (DS135), Korea-Various Measures on Beef (DS161, DS169), Dominican Republic - Import and Sales of Cigarette (DS302). For GATT Article I (the MFN obligation), see Indonesia-Autos (DS54, DS55, DS59, DS64), Canada-Autos (DS139, 142). 
would be subject to a larger tax, it is expected to be found to be discriminatory against steel from that country.

WTO law also allows border adjustments on exportation of goods. A border adjustment on exportation is usually made in the form of export rebates of or an exemption from taxes which would have been levied on the same products had they been destined for domestic consumption. This is a widespread practice for Value Added Taxes (VATs) and excise duties. From a WTO law perspective, border adjustments on exportation are subject to the MFN rules and WTO disciplines on subsidies. In addition to the issues posed by MFN rules described previously, export rebates may run afoul of rules on subsidies. Furthermore, for a tax to be adjustable on exportation, a tax or charge should be "borne by the product". ${ }^{39}$ Whether carbon taxes imposed in connection with PPMs, particularly the carbon-intensity of the production process, can qualify as "borne by the product" is an open question.

Thus, all in all, there is a high possibility that BCAs based on PPMs would fail to comply with the WTO legal framework for border adjustments.

The least discriminatory BCA design would be based on BAT. Border adjustments set at the BAT level would likely translate into the lowest tax rates for imported products. ${ }^{40}$ In this case, the tax level would be equal to or below what like domestic products face, hence imported products would not be discriminated against like domestic products. $^{41}$

Second-best with respect to the risk of discrimination claims would be the PMP method. However, under the PMP, the situation where the actual carbon footprint of imported products is lower than what it would be deemed to be under the PMP is more likely to occur than under the BAT. As such, measures would need to be taken to avoid discrimination claims, for example, the BCA scheme of the importing country could give foreign producers/importers the option of submitting information on their

\footnotetext{
${ }^{39}$ According to Article VI:4 and Ad Article XVI of the GATT and footnote 1 of the WTO Agreement on Subsidies and Countervailing Measures (ASCM).

40 Roland Ismer and Karsten Neuhoff, "Border tax adjustment: a feasible way to address nonparticipation in emission trading”, CMI Working Paper 36 (University of Cambridge 2004), at pp. 15-16, available on the Internet at http://econpapers.repec-org/paper/camcamdae/0409.htm (last accessed on 18 March 2012).

${ }^{41}$ Ibid.
} 
products actual carbon footprint in the case where their actual emissions are lower than the PMP. ${ }^{42}$

Adjustments made based on the average emissions in the corresponding sector of the importing country might be more discriminatory than the PMP method because imported products may gain less favourable treatment than the treatment received by the majority of locally produced products. Such an average can be challenged in the WTO. Moreover, from the perspective of the NT requirement the problem with both a PMP based BCA and the emissions average is that imported products would be taxed in excess of some of the like domestic products (under the classical concept of likeness), particularly those like domestic products produced with the emissions below the PMP or the average level of emissions benchmarks. ${ }^{43}$

It should be noted that for any of these methods, GATT Article XX could be used to defend violations of rules of the GATT. GATT Article XX provides for general exceptions to the GATT disciplines under certain conditions. To be eligible for the exceptions, BCAs would need to be acknowledged by a WTO panel or the Appellate Body as measures necessary to protect human, animal or plant life or health ${ }^{44}$, and/or as measures related to the conservation of exhaustible natural resources ${ }^{45}$. It is likely that BCAs could meet both of these provisions. Carbon pricing is put in place to protect people from the increased frequency and scale of natural disasters and their health from the increased scale of tropical diseases as a result of global warming. In addition, the climate may be viewed as an exhaustible resource, the conservation of which is the objective of carbon pricing.

However, there are other conditions under Article XX, with which BCAs would have more difficulty complying with. The chapeau of Article XX requires that measures not

\footnotetext{
${ }^{42}$ ZhongXiang Zhang, "Encouraging Developing Country Involvement in a Post-2012 Climate Change Regime: Carrots, Sticks or Both?” in Climate and Trade Policies in a Post-2012 World (UNEP 2009) at p. 83.

${ }^{43}$ When examining a measure on discrimination under Art. III:2 (i.e. a tax or charge), WTO panels and the $\mathrm{AB}$ are more likely to compare treatment of an imported product with any like domestic product (e.g. India-Additional Duties, paras 211-214), rather than a group of imported with a group of like domestic products as they do when examining a measure under Art. III:4 (i.e. a regulation) (e.g. See EC-Asbestos, AB report, para. 100). See Lorand Bartels, "The Inclusion of Aviation in the EU ETS: WTO Law Considerations”, Issue Paper no. 6 (ICTSD Global Platform on Climate Change, Trade and Sustainable Energy, ICTSD 2011), at p. 6.

${ }^{44}$ Under para. b) of Article XX.

${ }^{45}$ Under para. g) of Article XX.
} 
to be applied “in a manner which would constitute a means of arbitrary or unjustifiable discrimination between countries where the same conditions prevail, or a disguised restriction on international trade”. The imposition of BCAs, if those BCAs are based on PPMs, will affect some exporting countries (e.g. those with higher trade volumes of carbon-intensive products) more than others. To justify such discrimination, even if it is only de facto, could be difficult, especially if those countries are employing emissions reduction policies such as export taxes, energy-intensity targets etc. ${ }^{46}$ It would also be difficult to justify given the climate protection principle of common but differentiated responsibilities and respective capabilities agreed on by the global climate community. ${ }^{47}$ Therefore, to win the case of BCAs in the WTO dispute settlement will not be an easy task.

\section{PTAs and Climate Change}

Where PTAs overlap with climate change is two-fold. First, they reduce tariffs, in particular on industrial goods, the same goods that may be subject to carbon costs in developed countries. Second, they can contain environmental provisions related to climate change.

\section{Tariff Reductions}

Most PTAs include measures that would eliminate tariffs on industrial goods. For example, under the recently completed EU - South Korea FTA, the EU will eliminate all of its import tariffs on industrial goods within five years and South Korea would remove all of its tariffs within seven years. ${ }^{48}$ More generally, a review of PTAs in place by both the US and EU found that existing PTAs provide for nearly $100 \%$ elimination of all tariffs on industrial goods. ${ }^{49}$

\footnotetext{
${ }^{46}$ Joost Pauwelyn, "U.S. Federal Climate Policy and Competitiveness Concerns: the Limits and Options of International Trade Law" (Nicholas Institute for Environmental Policy Solutions, Duke University 2007), at pp. 37-41, available on the Internet at http://nicholasinstitute.duke.edu/climate/policydesign/u.s.-federal-climate-policy-and-competitivenessconcerns-the-limits-and-options-of-international-trade-law (last accessed on 30 April 2012).

${ }^{47}$ Article 3.1 of the UNFCCC.

${ }^{48}$ W.H. Cooper et al., The EU-South Korea Free Trade Agreement and Its Implications for the United States, Congressional Research Service Report for Congress (2011), at p. 12.

${ }^{49}$ R.J. Ahearn, Europe's Preferential Trade Agreements: Status, Content, and Implications, Congressional Research Service Report for Congress (2011), at pp. 15-16.
} 
While these tariff reductions will have benefits for both parties, developed country industries may be concerned about the competitiveness impacts of allowing increased access to their markets. For example in the debate leading up to the conclusion of the US-South Korea trade agreement, the U.S. steel industry registered a strongly negative position on the agreement, citing at least in part, the on sided nature of the agreement with respect to the American automotive industry. ${ }^{50}$

Climate policy raises competitiveness concerns for the same industries as those that are most affected by PTAs, including for example iron and steel, aluminum, cement and chemicals ${ }^{51}$. The proliferation of climate policies will therefore only exacerbate the competitiveness concerns that arise through the creation of PTAs.

From the perspective of EU companies BCAs lessen the competitiveness impacts on industry which might be particularly important in the face of increased competition from PTAs. From the perspective of developing nations, a PTA might mitigate some of the competitiveness impacts of BCAs. As a result, in some ways, the combination of BCAs and FTAs provides an opportunity for a win-win outcome.

\section{Climate Provisions in PTAs}

Recently a body of work is emerging on the role of climate policy in regional and bilateral economic arrangements. Among the most discussed is a proposal by Chatham House in 2008 for carbon free trade zones. These zones would be designed to "create an enabling environment for large-scale innovative low carbon private and public investment”. ${ }^{52}$ These zones, modeled on Special Economic Zones, would primarily benefit the development of low carbon technologies. ${ }^{53}$

Other work on this issue has classed the use of bi-lateral and uni-lateral action into three types, the first modeled on the Chatham House proposal, the second, the

\footnotetext{
${ }^{50}$ Supra note 49 , at pg. 26

${ }^{51}$ For a list of sectors identified by the EU as at risk of carbon leakage see 2010/2/:Commission Decision of 24 December 2009 determining, pursuant to Directive 2003/87/EC of the European Parliament and of the Council, a list of sectors and subsectors which are deemed to be exposed to a significant risk of carbon leakage (notified under document C(2009) 10251) Text with EEA relevance.

${ }^{52}$ Chatham House and E3G, Low Carbon Zones - A transformational agenda for China and Europe (2008), at p. 9 available on the Internet at http://www.e3g.org/images/uploads/Low_Carbon_Zones_EUChina_cooperation.pdf (last accessed on 18 March 2012).

${ }^{53}$ Ibid., at p. 9.
} 
unilateral imposition of BCAs and a third modeled on the methods in the Montreal Protocol, where a group of nations would agree on the extent of environmental action and impose sanctions or other forms of injurious trade measures against those parties that do not become parties to the agreement. ${ }^{54}$

An additional area where bilateral negotiations might be useful with respect to climate policies is where two countries agree to establish emissions reduction systems (e.g. ETSs) in their territories. In this case, provisions may be included in PTAs or other bilateral agreements to ensure the mutual recognition of the countries policies and avoid any future trade measures between countries. ${ }^{55}$

There is little work that has been done to explore the possibility of using PTAs to impose BCAs. The remainder of the paper focuses on this aspect - how PTAs could potentially be used to put in place BCAs in order to address issues related to carbon leakage and competitiveness concerns.

\section{BCAs in PTAs}

There are several high-level reasons why including BCAs in bilateral PTAs would be more appropriate than either imposing them unilaterally or negotiating them through multi-lateral agreements. However while the rationale for implementing BCAs in PTAs may be strong, there are none-the-less a number of implementation hurdles that would need to be surmounted in order for them to be truly feasible. The following discusses both the rationale for, and the implementation issues with, the imposition of BCAs in PTAs.

\section{Rationale for including BCAs in PTAs}

There are a number of strong arguments for including BCAs in PTAs. Currently BCA proposals are generally considered for application unilaterally. However, many claim that such unilateral measures will provoke trade retaliatory measures that can be harmful to economies at large and, in the worst case scenario, result in a full out trade

\footnotetext{
${ }^{54}$ Y. Dong and J. Whalley, Carbon, Trade Policy, and Carbon Free Trade Areas (2008), at pp. 4-5.

${ }^{55}$ Peter Holmes, Tom Reilly and Jim Rollo, "Border carbon adjustments and the potential for protectionism”, 11 Climate Policy (2011).
} 
war. $^{56}$ As such, while the unilateral imposition of BCAs is certainly a possibility, it carries many risks. A further argument against applying BCAs unilaterally is that, while competitiveness and carbon leakage concerns arise from concern over a country's largest trading partners being without commensurate climate costs, BCAs would impose those costs on all countries, even countries with very small market shares. This method may be unnecessary from the perspective of protecting competitiveness.

A multi-lateral agreement on the conditions under which BCAs would be applied is the ideal solution as it would avoid any retaliatory measures. ${ }^{57}$ However, multi-lateral forums can be cumbersome to negotiate in and therefore can take time to come to agreement. The Doha round of WTO negotiations, which began in 2001, is in its eleventh year of negotiation and is in dire straits; while the negotiations are officially ongoing many are declaring them dead. ${ }^{58}$ Similarly, while the latest UNFCCC conference in Durban did reach agreements on the continuation of the Kyoto Protocol, the establishment of a green fund on climate change and a commitment to reach a legally binding agreement by 2015, there is still some skepticism that the forum can yield real results. ${ }^{59}$ It is also questionable whether the UNFCCC could provide a useful negotiating forum for managing trade related measures such as BCAs.

Finally, the application of BCAs in PTAs may have advantages from a legal perspective, that is, there may be more flexibility with respect to trade law in PTAs than there is for provisions applied within the WTO legal framework. Most importantly, the application of BCAs only between PTA parties will not constitute a violation of the MFN principle, as the non-MFN application of "duties and other restrictive regulations of commerce" is allowed when the measures are taken under a PTA. Therefore, from a WTO compliance perspective, the application of BCAs under

\footnotetext{
${ }^{56}$ News reports have widely criticized these measures, pointing to their potential trade ramifications see for example "Climate issues at WTO may lead to 'trade war'", Business Standard, June 14, 2010 and "One easy way to start a trade war", Financial Times, Editorial, December 9, 2009.

57 J. Werksman et al., Trade Measures and Climate Change Policy: Searching for Common Ground on an Uneven Playing Field (World Resources Institute 2009).

${ }^{58}$ News reports following the failure of agreement in 2011 have widely reported the talks as stalled, see for example L. Herman and G.C. Hufbauer, "Doha is Dead", Foreign Policy, 26 September 2011, and “The Doha Round - Dead Man Talking”, The Economist, 28 April 2011.

59 “Cool response to Durban compromise”, 2 Nature Climate Change (2012), at p. 59.
} 
a PTA eliminates the risks of violation of GATT Article I, which, as discussed above, is likely in the case of the application of BCAs in non-preferential trade.

It should be noted that from a strictly legal perspective there are hurdles to the implementation of BCAs that would prevail even in the case of implementation through PTAs. Except for the allowed derogation of the MFN principle, all other WTO rules regulating the application of BCAs are supposed to be followed. The violation of WTO rules applicable to BCAs might only be excused, if it could be argued that the PTA could not have been concluded, had the provisions on the application of BCAs not been included in the agreement. ${ }^{60}$ This situation is hard to imagine; it is much more likely that BCAs act as an obstacle to the conclusion of a PTA, which a developed country manages to overcome by offering something else in compensation to its PTA partners. ${ }^{61}$

Furthermore, since BCAs are meant to apply only to trade among PTA parties, they would constitute trade restrictions on internal trade between PTA parties, and, hence, would be subject to the so-called "internal requirement" for regional liberalization contained in paragraph 8 of GATT Article XXIV. ${ }^{62}$ GATT Article XXIV:8 requires that for free trade areas "duties and other restrictive regulations of commerce (except, where necessary, those permitted under Articles XI, XII, XIII, XIV, XV and XX) are eliminated with respect to substantially all the trade between the constituent territories”. Despite the existing uncertainties among WTO members with respect to the meaning of "other restrictive regulations of commerce" and "substantially all the

\footnotetext{
${ }^{60}$ The Appellate Body in the Turkey-Textiles case (Turkey - Restrictions on Imports of Textile and Clothing Products, WT/DS34/AB/R, para. 58) held that

“...Article XXIV may justify a measure which is inconsistent with certain other GATT provisions. However, in a case involving the formation of a customs union, this "defence" is available only when two conditions are fulfilled. First, the party claiming the benefit of this defence must demonstrate that the measure at issue is introduced upon the formation of a customs union that fully meets the requirements of sub-paragraphs 8(a) and 5(a) of Article XXIV. And, second, that party must demonstrate that the formation of that customs union would be prevented if it were not allowed to introduce the measure at issue. Again, both these conditions must be met to have the benefit of the defence under Article XXIV". ${ }^{60}$ (italics added).

${ }^{61}$ It should be noted that this scenario could be averted should the carbon price be applied through import duties rather than BTAs, as in this case the NT obligation would not apply. However, for the sake of brevity, this paper does not delve into the details of other formulations of BCAs.

62 The „external requirement“ contained in paragraph 5 of GATT Article XXIV applies only to measures („,duties and other regulations of commerce“) imposed upon the formation of a PTA on nonparties (i.e. third countries).
} 
trade" ${ }^{63}$, it is likely that not only carbon import duties but also carbon import taxes and importer allowance requirement would fall into the scope of Article XXIV:8 and as such would violate the requirement of "substantially all the trade" liberalization.

From a legal perspective, these problems could be surmounted through recource to the exception clauses under GATT Article XX, which, as discussed earlier, are still available provided that the BCAs meet the requirements of Article $\mathrm{XX}$, including those of the Chapeau. ${ }^{64}$.

Despite the probability of a conflict of BCAs taken under a PTA with WTO rules, the likelihood of their challenge in the WTO is low, making the application of BCAs under a PTA a more attractive policy choice compared to the unilateral application of BCAs on an MFN basis across the board. If BCA provisions are included in a PTA, it seems logical that PTA parties accept these measures as previously agreed, and provided their application follows the agreed rules and criteria, will not complain about them in the PTA dispute settlement or at the WTO. With respect to non-parties to a PTA, they would have no reason to complain as long as BCAs are applied only to trade between PTA parties and, hence, do not nullify or impair benefits to third parties under the WTO Agreement. For these reasons, while the legal hurdles remain, due to the practical limits on the likelyhood of any breaches in law being brought to dispute resolution, implementing BCAs trough PTAs could be far more feasible than if done unilaterally.

\section{Implementing BCAs in PTAs}

The largest barrier to using PTAs to impose BCAs is with respect to its effect on trade flows. Border adjustments are in general applied across the board. That is when a BCA

\footnotetext{
${ }^{63}$ Neither GATT/WTO panels and the Appellate Body, nor GATT contracting parties/WTO members through negotiations in GATT working parties on RTAs or the modern day WTO Committee on Regional Trade Agreements could so far have clarified the meaning of the terms. For instance, pursuant to the holding of the $\mathrm{AB}$ in the Turkey-Textile dispute, the "substantially all the trade" is likely to be assessed in terms of both quantity (trade volumes) and quality (sectoral coverage). Yet, how much or how inclusive it has to be, there is no agreement. In terms of quantity, for example, various benchmarks of 80, 90 and 95\% of total trade have been proposed. See Petros C. Mavroidis, "If I Don’t Do It, Somebody Else Will (Or Won't): Testing the Compliance of Preferential Trade Agreements With the Multilateral Rules”, 40(1) Journal of World Trade (2006), at p. 200.

${ }^{64}$ It should be noted that a country imposing a BCA measure under a PTA could seek defense under Article XX also for other possible violations of GATT rules, including the national treatment principle. In this case, the defense would follow the usual course under Article XX, previously described for BCAs taken in non-preferential trade.
} 
is put in place it taxes all imports regardless of their country of origin and rebates funds on all exports regardless of the destination of those exports. If BCAs were to be applied to only one nation they could result in a rerouting of trade flows from the country with the PTA in place through third countries. For example suppose country A has a stringent climate policy in place and decides through a PTA to impose BCAs on imports from country B that has no policy in place. Leaving aside for the moment the rationale as to why country B might agree to such an arrangement, if the BCAs are higher than the MFN tariff rates applied to the imports of those products from other countries, there is no reason why producers from country B would not simply export their products first to a third party who would then export them to country A at the lower MFN rates. As a result in general a BCA applied only to one country could be ineffective. However, whether or not the rerouting of trade would in fact occur will depend on the BCA levels, which will in turn depend on the design of the BCA, the sectors to which they are applied and the carbon price.

In addition, there may be ways for BCAs to be imposed in bilateral agreements and to avert the rerouting of trade flows.

1) Rules of origin - MFN rates apply to products regardless of their origin. It may be possible to adjust the rules of origin such that products from a country receive the carbon related rates (i.e. PTA rates that are higher than the MFN rates) rather than the MFN rates regardless of which country the products were finally imported from. For example should a PTA conclude that products from a certain country would receive the larger than MFN carbon related rates, rules of origin could state that these rates apply to products where the majority of value was added in that country, regardless of the final point of import. There are several complications with this option, most notably the legality of such a system as well as how to entice a country to accept through its PTA a higher than MFN tariff rate for some of its products.

2) Carbon rates that are less than MFN rates - In a PTA tariff rates on most products are adjusted to zero. However, if in the case of a BCA, the net tariff rates on certain emissions intensive products are not adjusted to zero but to some other rate that is below the MFN tariff levels the deflection of trade flows to third parties would not occur. This may not result in the full 
pricing of carbon and therefore may not address all competitiveness concerns fully, however it would take the first step towards addressing the issue.

Finally, PTAs may be useful in applying BCAs even in the situation where BCAs are not applied in a bilateral agreement. Specifically they may provide a useful forum for negotiations with the largest trading partner. That is, even where a BCA is applied to all nations it is the largest trading partner or partners of the country imposing the BCA that are likely to have the greatest objection to the measure. Therefore, including BCAs as part of a PTA negotiation could enable the country imposing the BCA to work out the design details to the satisfaction of its largest trading partner and potentially offer concessions to elicit agreement to the BCA. While this does not eliminate all potential trade related conflicts over its imposition, it may eliminate the bulk of them, making this a useful endeavour. It could also serve as the forum through which a country could try to entice a second party to impose stringent climate policies of its own. However in order for this to be effective the threat would need to be credible, i.e. the country would have to be willing to put in place the BCAs unilaterally regardless of the outcome of the negotiation.

The remainder of this section will explore each of the ways in which BCAs may be usefully employed in PTAs in detail reviewing both the economic and legal implications and giving examples as to how they might work in practice.

\section{a. Rerouting of trade flows}

Whether trade flows will be rerouted as a result of the unilateral imposition of BCAs will depend on the magnitude of the BCA, that is, whether the BCA rate is above or below the MFN tariff rate. This in turn will depend on a number of factors including, the sector to which it is applied, the carbon price and whether the tariff level is set based on the emissions intensity of the importing country or the exporting country.

Some analyses have been completed in an attempt to judge the magnitude of BCAs, however the results vary widely. A study by Dong and Whaley found that the magnitude of BTAs applied in the EU for high emissions intensity goods would range from $0.36 \%$ to $2.9 \%$ for carbon prices ranging from $\$ 25$ per tonne to $\$ 200$ per tonne. $^{65}$ 
However this study notes that the values would be significantly higher if indirect emissions and the emissions intensities in the exporting country were to be used.

A second study from the Center for Global Development shows results that are significantly higher. It finds that in order for industrialized countries to reduce emissions by $17 \%$, BTAs imposed on energy intensive manufacturing in China could range from around $7 \%$ when the carbon intensity of the importing country is used to over $40 \%$ when the carbon intensity of the exporting country is used. However this analysis was premised on a carbon price exceeding $\$ 300$ per tonne. ${ }^{66}$ Finally, a study from the International Institute for Sustainable Development looked at the steel sector in China specifically and found that for a \$20 per tonne carbon price a BTA of around $8 \%$ would be needed.

We have completed a basic analysis to give an illustrative example of the rates that would be necessary for BCAs using trade volumes from the World Integrated Trade Solutions (WITS) database and emission intensity figures from an OECD study. ${ }^{67}$ The analysis uses average emissions intensities by sector for both China and the EU to give an idea of what a BAT-style or a PPM-style BCA would look like. Therefore what is deemed to be a PPM-style BCA could also be a BCA set based on the PMP or average emissions of the exporting country and what is deemed a BAT-style BCA could also be a BCA based on PMP or average emissions of the importing country.

Table 1 shows a basic calculation of BCAs applied to steel and aluminum exports from China into the EU. It also shows the MFN tariff rates for these products. For steel the MFN tariff rates are already very low and the emissions intensity of steel

Internet at http://economics.uwo.ca/centres/epri/wp2009/dong_whalley_03.pdf (last accessed on 18 March 2012).

66 A. Mattoo et al., "Reconciling Climate Change and Trade", Policy Center for Global

Development Working Paper 189, available on the Internet at

http://www.cgdev.org/files/1423204_file_Subramanian_Climate_and_Trade_FINAL.pdf (last accessed on 18

March 2012).

${ }^{67}$ Emissions intensities from N. Ahmad and A. Wyckoff "Carbon Dioxide Emissions Embodied in International Trade of Goods”, OECD Science, Technology and Industry Working Papers, 2003/15 (OECD Publishing 2003), at p. 26. Trade volumes from World Integrated Trade Solutions Database http://wits.worldbank.org/wits/, 2010 trade volumes. The carbon price used in this analysis is \$20/tonne. Current carbon prices in the EU ETS are around 12-13 euros, or \$16-\$17/tonne. Estimates find that the EU ETS 2020 target should be able to be met with only a small increase in this price. However, higher prices will likely be necessary to meet targets in the post 2020 period. See Press Release: Emissions are Under Priced in Europe, Bloomberg New Energy Finance, September $13^{\text {th }}$, 2011, available on the Internet at http://www.newenergyfinance.com/PressReleases/view/165 (last accessed on 18 March 2012). 
production is high both in China and in the EU. As a result in almost all cases the BCAs for steel would likely be higher than MFN tariff rates and the unilateral imposition of such adjustments would likely result in the rerouting of trade flows, albeit in our calculation the BAT based BCA on steel is not much higher than the MFN tariff rate. However, the case is different for aluminum where existing tariffs are higher and the emissions intensity of production is lower. In this case, for lower carbon costs, or where BCAs are of BAT-style, it is possible that BCAs would be lower than MFN tariff rates and the unilateral imposition of BCAs would in fact be feasible.

Table 1 Calculation of BCAs applied to steel and aluminum exports from China into the $E U^{68}$

\begin{tabular}{|l|r|r|}
\hline Scenario description & Aluminum & Steel \\
\hline Current Tariffs & \multicolumn{3}{|l|}{} \\
\hline Existing MFN Tariffs - no carbon price & $6.5 \%$ & $1.7 \%$ \\
\hline PPM style tax applied to all emissions & \multicolumn{3}{|l|}{} \\
\hline Carbon Price applied to all Chinese emissions (\$20/tonne) & $6.8 \%$ & $12.7 \%$ \\
\hline BAT style tax applied to all emissions & & \\
\hline Carbon Price applied to EU emissions (\$20/tonne) & $0.6 \%$ & $2.3 \%$ \\
\hline
\end{tabular}

Therefore, it is likely that the chances of trade deflection that would result from a BCA applied to only one country would depend on the sector to which the BCA is applied, the manner in which it is applied and the carbon price. Because the emissions intensity of production is lower in the EU than in many developing countries, using a BATstyle method for applying BCAs may be sufficient to avoid the rerouting of trade flows and enable BCAs to be applied to single countries rather than across the board. However, further sector specific analysis would be necessary to confirm this result.

\section{b. Rules of origin}

Rules of origin are a common feature in PTAs. They are primarily used to avoid a particular type of trade deflection, that is, to avoid countries selling their products through third parties in order to take advantage of low tariffs in the PTA. For example, the South Korea-EU FTA sets out rules that define the extent to which goods not wholly originating in South Korea can qualify for FTA provisions. Rules of origin

\footnotetext{
${ }^{68}$ Emissions intensities from Ahmad, N. and A. Wyckoff (2003), “Carbon Dioxide Emissions Embodied in International Trade of Goods", OECD Science, Technology and Industry Working Papers, 2003/15, OECD Publishing, p. 26. Trade volumes from World Integrated Trade Solutions Database http://wits.worldbank.org/wits/, 2010 trade volumes.
} 
may also be useful in applying BCAs if they were to be applied selectively to certain countries. That is, should a BCA be applied to a single country or a series of countries rather than all trading partners, and if those BCAs were to be set above current MFN tariff rates there is the serious risk that goods from the country to which the BCA is applied would simply be shipped to a third party and then to the final destination in order to take advantage of MFN tariff rates rather than the higher BCA rates. In order to avoid this situation, rules of origin could be used to discriminate between goods originating in different countries. For example if a BCA were applied against Chinese goods, then that BCA could be applied to goods where the majority of value added was in China, regardless of where the goods were finally exported from. If such rules of origin could be designed it would allow for BCAs to be set above MFN tariff rates for selected countries. This would be especially useful where BCAs would be set based on PPMs for highly carbon-intensity products such as steel. Of course, as mentioned earlier such a design would require that the country imposing the BCA provide sufficient incentives through concessions in its PTA to the country to which these BCAs would be applied against, to entice the country to in fact sign on to such a provision.

With respect to the legal implications of the rules of origin approach to trade deflection, there are no WTO disciplines on rules of origin used in PTAs (preferential RoOs). ${ }^{69}$ Therefore, in principle, WTO members are free to design RoOs in their PTAs as they want. ${ }^{70}$ For this reason, this work around may in fact be feasible.

However, beyond the barriers posed by designing rules of origin, setting BCA rates above MFN tariff rates may result in other legal isues. Specifically, setting BCA rates in a PTA above MFN tariff rates is likely to be found not only in violation of the "substantially all the trade" requirement of Article XXIV:8 but, in the case where

${ }^{69}$ There are WTO disciplines on the preparation and application of non-preferential RoOs, which are contained in the WTO Agreement on Rules of Origin (RoOs Agreement) attached to Annex 1 of the WTO Agreement. The disciplines however are quite general. Pursuant to Article 5 of the Agreement on Rules of Origin, it is allowed to change and introduce new RoOs provided that this is duly notified to the WTO Secretariat.

70 The multitude of diverse and sometimes overlapping RoOs in PTAs increase transaction costs for firms and make their use of preferences offered by PTAs difficult or even impossible. Preferential RoOs are thus often viewed as a significant trade barrier, which dillutes effects of liberalisation in PTAs. Consequently, the liberty of setting RoOs is perceived in the WTO as the wrong tradition, which has to be corrected through WTO negotiations aimed at harmonisation of preferential RoOs via use of cumulation rules. See World Trade Report 2011 at note 2 , at pp. 83, 108-109, 188. 
BCA rates exceed bound tariffs in the country's Schedule of Concessions, it might also constitute a violation of GATT Article II. Yet, the measure might be justified under general exceptions of GATT Article XX. However, given that we assume agreement has been reached on these levels through the PTA, it may be unlikely to face any challenge.

A secondary issue that arises from the selective application of BCAs is the question of how national exports will be treated. In the unilateral imposition of BCAs export rebates are given to all exporters of carbon-intensive goods regardless of the destination of these goods. However, in the bilateral imposition of BCAs the question arises as to whether rebates should still given in this way or whether they ought to be given only to those exports destined for the PTA partner. Depending on market shares, export rebates may need to be applied to all countries to which those products are destined, even if import BCAs are being applied to only one country. However, there is no provision in the WTO Agreement saying that an export-side border adjustment (BA) must always accompany import-side BA, i.e. import BAs can arguably be applied without parallel rebates on exportation. In addition, it is possible that rebates applied as selective export rebates (in PTAs) could still be effective, as in the case where the PTA partners is the largest export market for the particular products of a BCA-imposing country.

\section{c. Carbon rates less than $M F N$ rates}

A second possible role for PTAs in negotiating BCAs is to use the PTAs to set BCA rates below current MFN tariff rates but above zero. This possibility is premised on the idea that PTAs that move the tariff rates on industrial products to zero are likely to occur anyways, as a result setting BCAs above zero but below MFN rates would be an improvement on the status quo from a carbon pricing perspective. Under this scenario, the PTA would still provide benefits to the developing country sectors concerned but not to the same extent as would occur had the tariffs been lowered to zero as would be the case in an ordinary free trade agreement. The primary issue with this method is that tariffs on many products are already low, which means that by taking this method tariffs would likely be set below the actual carbon costs.

For example, the average MFN tariffs on imports of raw steel by the EU from China are very low, $0.13 \%$, the average tariffs on steel products are higher but still not 
substantive at $2.31 \% .{ }^{71}$ While the tariffs on steel products are significantly below the $12.7 \%$ that would be necessary to capture the carbon costs using a $\$ 20$ per tonne price applied to Chinese emissions, when that cost is applied using an EU emissions intensity, a metric that is comparable to using a BAT or PMP mode of levying tariffs, the tariff rates would only need to be $1.1 \%$, a level that would allow for a reduction in MFN tariff levels. ${ }^{72}$

This may also be a more feasible way forward for other sectors. For example the aluminum sector has much higher tariff levels than the steel sector, with average MFN rates on the order of $6.5 \%{ }^{73}$ It is also a sector with lower emissions intensities, a \$20 per tonne carbon tax applied to Chinese emissions from the aluminum sector would require a $6.8 \%$ tariff. $^{74}$ Therefore a BCA set slightly below the PPM based BCA would still capture the majority of carbon costs but would be low enough to provide some advantage from the PTA to developing countries.

From a legal perspective, provided BCAs are set below MFN tariff rates and provided that the inclusion of BCAs in a PTA in this manner is found to satisfy "the essentially all the trade” rule of GATT Article XXIV:8, such a BCAs design would not face any legal hurdles. For this reason this option may be the most feasible from the perspective of its practicality.

\section{d. Negotiations with the largest trading partner}

Negotiations with the largest trading partners could prove helpful in garnering support for BCAs applied across the board. For many of the industries that are most vulnerable to carbon leakage and competitiveness impacts a few trading partners make up the bulk of trade, meaning that working with these countries could go a long way towards building support for the BCAs.

\footnotetext{
71 World Integrated Trade Solutions Database http://wits.worldbank.org/wits/

72 Based on data from Emissions intensities from N. Ahmad and A. Wyckoff 2003 and trade data from World Integrated Trade Solutions Database http://wits.worldbank.org/wits/, 2010 trade volumes.

73 World Integrated Trade Solutions Database http://wits.worldbank.org/wits/

74 Based on data from Emissions intensities from N. Ahmad and A. Wyckoff 2003 and trade data from World Integrated Trade Solutions Database http://wits.worldbank.org/wits/, 2010 trade volumes.
} 
For raw iron and steel the top 5 exporting countries to the EU made up almost $50 \%$ of EU imports in 2010. For products of iron and steel the top three exporting countries make up 50\% of EU imports. For both of these categories China is the largest exporting country to the EU, making up 36\% of imports of iron and steel products and $15 \%$ of imports of raw iron and steel. ${ }^{75}$ As a result, for example, the EU working with China to gain support for a BCA could be helpful in ensuring widespread acceptance of the BCA. However, the extent to which negotiations will be successful will depend on the ability to, to some extent, compensate for these economic impacts.

PTAs are expected to have significant economic benefits. The EU-South Korea FTA is estimated to result in increased imports to the EU from South Korea of up to 34 billion euros and to increase exports from the EU to South Korea of between 33 and 41 billion euros. ${ }^{76}$ The trade benefits of a PTA with larger countries are likely to yield even larger benefits. A simple analysis of reducing tariffs on all non-agriculture goods imported by the EU from China would yield over 20 billion in trade benefits. ${ }^{77}$ This value does not include any tariff reductions on agriculture products or services but is none the less substantial. By contrast a $12.7 \%$ tariff on all the steel imports from China amounts to less than 1.5 billion USD, an additional reduction in steel trade of $10 \%$ would add an extra 1 billion USD to the total. ${ }^{78}$ Thus, even with conservative estimates of zero cost pass through and large reductions in trade, the costs of added tariffs on this important sector are much smaller than the gains that could be achieved by a PTA.

For these reasons, it would seem that PTAs may provide valuable benefits in excess of the costs of carbon tariffs and as a result could provide a useful forum to use increased access to markets to encourage developing countries to take on the added burden of carbon-related border adjustments for the sake of climate change mitigation.

\footnotetext{
75 World Integrated Trade Solutions Database http://wits.worldbank.org/wits/, 2010 trade volumes.

${ }^{76}$ Y. Decreux, The Economic Impact of the Free Trade Agreement (FTA) between the European Union and Korea, Report for the European Commission (2010), available on the Internet at http://trade.ec.europa.eu/doclib/docs/2010/may/tradoc_146174.pdf (last accessed on 18 March 2012).

77 Simulation of the application of zero tariffs on all non-agriculture goods using the SMART simulation available World Integrated Trade Solutions Database http://wits.worldbank.org/wits/, 2010 trade volumes.

78 Based on data from Emissions intensities from N. Ahmad and A. Wyckoff 2003 and trade data from World Integrated Trade Solutions Database http://wits.worldbank.org/wits/, 2010 trade volumes.
} 


\section{Conclusions}

PTAs are increasing in prevalence worldwide and in particular between developed and developing countries. And, while some analysts are less than pleased with this pattern, the move towards these agreements as a backbone for trade liberalization appears to be inevitable. In order for stringent climate policies to be put in place the inclusion of some method of addressing the competitiveness and carbon leakage concerns of specific large industries also seems inevitable, and BCAs are one of the most prevalent means of addressing these impacts that has been discussed to date. As a result the inclusion of BCAs in PTAs is almost certainly an idea that ought to, at the very least, be explored.

The inclusion of BCAs in PTAs has several distinct advantages; it would ensure the unilateral imposition of BCAs does not result in full out trade wars, it does not rely on cumbersome and often ineffective multi-lateral discussions and it is perhaps more legally feasible as it provides a method of, to some extent, circumventing barriers to the unilateral BCA implementation posed by WTO rules. However the implementation hurdles associated with such a system are not insignificant and would require further thought and analysis to ensure they are surmountable.

Of the options explored regarding the role of BCAs in PTA negotiations perhaps the most likely and feasible is the use of PTA negotiations as a forum for garnering support for unilaterally imposed BCAs. This option presents no legal hurdles nor does it create any trade impacts beyond those normally faced by BCAs. The primary disadvantage of this option is that it may not be fully effective in avoiding the trade retaliatory measures that may arise from the unilateral imposition of BCAs. That is, even if the largest trading partners agree to the imposition of a BCA, it does not mean that countries with smaller market shares will not none the less voice their discontent through retaliatory trade measures.

The second most feasible means of implementing BCAs through bilateral agreements is through the imposition of tariff levels that are less than MFN rates but above zero. This method would ensure the imposition of the BCA does not result in the rerouting of trade and is likely very feasible from a legal perspective. The disadvantage however is that due to already low MFN tariff levels it is unlikely that tariffs would capture the full carbon costs of imported goods and therefore would not be as effective as desired from either an environmental or a competitiveness perspective. 
Finally other more original solutions such as changes in the rules of origin may be possible, however such ideas require further analysis to determine their feasibility due to the sheer novelty of such an approach.

This paper provides a first blush look at the possibility of including BCAs in PTAs. Clearly further analysis would be required in order to arrive at a true assessment of their feasibility. However, it does show that this option has potential and is an area that merits further consideration. 